\title{
La conquista del noroeste argentino y los cultivos europeos
}

\author{
Marco Giovannetti \\ Universidad Nacional de La Plata, Argentina \\ vslema@hotmail.com
}

\begin{abstract}
Resumen
En el presente artículo se analiza la introducción de cultivos de origen europeo, como el trigo y la cebada, entre otros, en el territorio del actual noroeste argentino durante los primeros momentos de la conquista española, en la segunda mitad del siglo XVI y XVII. No se intenta solamente trazar el itinerario de los mismos, sino profundizar en su relación con el mundo indígena de la antigua gobernación del Tucumán colonial. Las interacciones entre los cultivos del Viejo Mundo y los grupos indígenas serán abordadas desde perspectivas tales como las posibilidades de apropiación y, especialmente, el consumo de los productos agrícolas, situando toda esta problemática en un contexto sociohistórico caracterizado por la conquista, imposición y dominio de las poblaciones nativas.
\end{abstract}

Palabras clave: ARGENTINA, CULTIVOS EUROPEOS, SIGLO XVI, SIGLO XVII.

\begin{abstract}
The aim of this paper is to investigate the introduction of European crops -such as wheat and barley among others- into the actual Argentinean Northwest territory during the early Spanish conquest in the second half of XVI and XVII centuries. We are not just trying to draw their itinerary, but to inquire into its relationship with the aboriginal world at the colonial Tucuman Government. Interactions between Old World crops and aboriginal groups will be analyzed from perspectives such as the possibilities of agricultural products appropriation and consumption. This analysis will be situated in a social and historical context characterized by the conquest, imposition and domain of the native populations. Key words: ARGENTINA, EUROPEAN CROPS, $16^{\mathrm{TH}}$ CENTURY, $17^{\mathrm{TH}}$ CENTURY.
\end{abstract}




\section{Introducción}

Los cultivos vegetales han aportado o, más específicamente, han sido el elemento de subsistencia fundamental para el desarrollo y evolución de los sistemas sociales humanos. En este sentido, no se puede concebir el estudio de la complejidad social sin enfrentar detenidamente el fenómeno de la agricultura que en algunas ocasiones fue acompañado -aunque no es siempre el caso- por la domesticación animal. Los "Estados prístinos" tienen una historia y un destino inexorablemente vinculado a las prácticas $\mathrm{y}$, por ende, a los productos agrícolas: en el lejano Oriente el arroz; en medio Oriente, el trigo y la cebada, entre otros de menor trascendencia; en África, el mijo y el sorgo; en Mesoamérica, el maíz, el poroto y las calabazas, al igual que la zona andina, salvando sus diferencias intrínsecas. Si bien Europa no registra el fenómeno comúnmente conocido como "invención agrícola", es partícipe de este proceso desde muy temprano, y ya en el Mesolítico se encuentran los indicios de las primeras comunidades cultivadoras de trigo, cebada y frutales. Los cultivos que los españoles introdujeron en América eran parte fundamental de su cultura e idiosincrasia, ya que acompañaron desde el principio todo el desarrollo Neolítico de dicho continente, o sea, 8.000 años aproximadamente.

En este trabajo abordaremos la problemática de la introducción de los cultivos europeos en América enfocando específicamente esta cuestión en el noroeste argentino (NO) o, en perspectiva histórica, la antigua jurisdicción de la gobernación del Tucumán ${ }^{1}$. La introducción de estos cultivos no implicó solamente su traslado desde Europa hasta América por los colonizadores, pues hay que tener presente la difusión de tales productos hacia los grupos nativos. De hecho, la difusión de elementos o patrones culturales desde un grupo humano a otro es un tema complejo y aún en pleno debate en la antropología. Se acepta que no hay solo un modelo explicativo para comprender cómo ciertos objetos o costumbres foráneas se instalan en el seno de una comunidad. Lo recomendable y más enriquecedor es abordar este fenómeno desde una perspectiva que abarque una multiplicidad de enfoques, atendiendo a las particularidades de cada grupo cultural, circunstancias y contingencias históricas y, en muchos casos, visualizando el papel de individuos emprendedores promotores del cambio. Un análisis dinámico y relacional de estos factores $-y$ de algunos otros que se nos escapan- es, en nuestra opinión, factible de aportar resultados. Por lo tanto, desde esta perspectiva, comenzaremos a analizar este proceso en el NOA a lo largo de los siglos XVI y XVII. Consideramos que este corte temporal, si bien no deja de ser arbitrario, es

\footnotetext{
${ }^{1}$ El noroeste argentino comprende las actuales provincias de Jujuy, Salta, Catamarca, La Rioja, Tucumán y Santiago del Estero. Incluiremos en este trabajo algunos aspectos de la actual provincia de Córdoba que, si bien actualmente no pertenece a esta región, fue partícipe, antes y en el momento colonial, de procesos culturales íntimamente relacionados, como parte de la antigua jurisdicción del Tucumán.
} 
coherente con los enormes procesos desestructurantes y situaciones de choque cultural que tuvieron que enfrentar las poblaciones autóctonas en este período, logrando algunas de ellas en el trayecto particulares formas de supervivencia y adaptación.

\section{Introducción de los cultivos europeos en el NOA}

Está establecido que las primeras acciones españolas en el Tucumán implicaron la fundación de ciudades constituidas a partir de un núcleo poblacional hispánico. Las crónicas nos informan que dicha población debía "sustentarse" mediante el cultivo de la tierra y la crianza de ganado de acuerdo con la concepción ibérica de la subsistencia y el ordenamiento de los grupos humanos en el espacio. Según entendemos aquí, esta concepción de la que hablamos tiene fuertes componentes identitarios que, en la mentalidad española de los colonos del siglo XVI y XVII, se tradujo en "transportar España a América", al decir de G. Baudot ${ }^{2}$. Específicamente, en cuanto a la alimentación agraria, los colonos españoles no solo reorganizaron la economía agrícola-ganadera de la región según la concepción que tenían de la misma, favoreciendo el cultivo en el llano por sobre el que se realizaba en andenes, por ejemplo, sino que también, con gran tenacidad, introdujeron una gran cantidad de especies provenientes de Europa.

Siguiendo esta idea, planteamos entonces ciertos interrogantes acerca de la problemática de los primeros cultivos europeos ${ }^{3}$ en los territorios del NOA. La ciudad del Barco de Ibatín fue la primera fundación en el Tucumán, erigida aproximadamente en el año 1550 por un enviado desde el Perú, Don Juan Núñez del Prado. Cabría esperarse -según lo planteado anteriormente y teniendo en cuenta la importancia de este primer asentamiento español- que quienes lo llevaron adelante se habrían procurado los elementos mínimos indispensables para la subsistencia, como ganado y especies vegetales comestibles, fundamentalmente trigo y cebada, para cultivar en las primeras sementeras. Al respecto, el ingeniero agrónomo J. Báez ${ }^{4}$ no duda en afirmar que tal fue lo sucedido, a pesar de los escasos fundamentos que esgrime, sin restarle el mérito de ser prácticamente el

\footnotetext{
${ }^{2}$ G. Baudot, La vida cotidiana en la América española en tiempos de Felipe II (México: Fondo de Cultura Económica, 1995).

${ }^{3}$ Como habíamos visto en la introducción al hablar de cultivos europeos, en realidad no estamos haciendo referencia a que fueran originalmente domesticados en Europa, aunque sí lo fueron en otras regiones del Viejo Mundo. Con esta designación solo rescatamos el hecho de que para el siglo XVI eran usualmente consumidos en Europa y, por lo tanto, fueron introducidos al Nuevo Mundo durante la conquista.

4 J. R. Báez, "La primera colonia agrohispana en el Tucumán (siglo XVI)", Revista Argentina de Agronomía (Buenos Aires), 14, núm. 2 (1947): 85-93; "La primera colonia agrohispana en Cuyo (siglo XVI)", Revista Argentina de Agronomía (Buenos Aires), 15, núm.1 (1948): 19-32.
} 
único investigador que ha estudiado el tema. Para esclarecer este punto, uno de los documentos mas importantes con los que cuenta es un informe llevado a cabo por Núñez del Prado en la ciudad del Barco, en 1551 -antes de someterse a la gobernación de Chile, en manos de Don Pedro de Valdivia-, donde hace constar los inconvenientes que trajo aparejada la llegada de Francisco de Villagrán, un lugarteniente de Valdivia. En este documento, un cuestionario de 28 preguntas, intenta justificar el traslado de dicha población e inculpa a Francisco de Villagrán de la hambruna sufrida por su gente, ya que, ante los repetidos intentos de Núñez de Prado para cultivar la tierra, el primero consume desmesuradamente y destruye los campos. Interesa destacar de este relato que todos los cultivos nombrados son americanos: maíz, quínoa, zapallo (auyama) y poroto. En un documento tan detallado como este y donde el autor intenta mostrar que agotó todos los recursos posibles para sustentar a la población, resulta sospechoso que no se nombraran los cultivos europeos que, en opinión de Báez, seguramente habrían llevado consigo. Esto nos induce a pensar que en este primer asentamiento o bien no se contaba desde un principio con semillas de cultivos europeos o por alguna razón los mismos no prosperaron. Consultando el documento original, o sea, la "probanza de mérito de Juan Núñez del Prado en la ciudad del Barco en 1551", se puede observar con precisión cual fue la suerte que corrieron las primeras cosechas en territorio del NOA en un pueblo español. A pesar de sufrir inconvenientes desde su llegada, Juan Núñez del Prado y su gente logran hacer dos sementeras, una en el mes de agosto de 1550 y en el mes de enero del siguiente año la otra. Dentro de las preguntas del cuestionario oficial figuraba lo siguiente:

Ítem si saben que dentro de dos meses, después que el capitán Juan Núñez de Prado pobló a esta ciudad, hizo meter en ella pasadas de dos mil fanegas de maíz y de trigo, y entrando el mes de agosto, que es el tiempo que los naturales siembran la primera sementera, hizo que todos sembrasen y para ello les dio a todos los indios caciques principales de los que habían venido de paz para con que hiciesen las dichas sementeras, y en el mes de enero adelante con otra sementera hizo hacer otra de las cuales dos sementeras se cogió muy poco maíz digan lo que saben ${ }^{6}$.

Una primera evaluación sobre esta pregunta nos permite obtener algunos datos. Primero, pareciera que se introdujo trigo para la alimentación inmediata en los primeros momentos del pueblo, y segundo, que si es que este se cultivó, no se obtuvo ningún resultado, ya que aparentemente apenas se pudo recoger algo de

\footnotetext{
5 "Probanza presentada en la ciudad de El Barco por Juan Núñez de Prado, su fundador, para señalar sus servicios y manifestar sus agravios contra el capitán Villagra", en R. Levillier, "Gobernación del Tucumán. Probanzas de méritos y servicios de los conquistadores", Documentos de Archivo de Indias, Colección de publicaciones históricas de la Biblioteca del Congreso Argentino (Madrid: Sucesores de Rivadeneyra S. A., 19191920), 1: 68-121.

${ }^{6}$ Ibídem.
} 
maíz de las primeras cosechas. El problema surge cuando se consulta a los testigos, pues, sorprendentemente, de los quince que declararon ninguno hace mención de que se ingresara trigo, ni siquiera desde el principio de su establecimiento en el lugar, pero sí recuerdan que se trajo maíz y que de los primeros cultivos solo este producto es el que se cosechó. Veremos algunos ejemplos para corroborar lo dicho.

a) El testigo Juan de Rentería contestó lo siguiente:

... a la veinte pregunta dijo que el dicho capitán hizo meter en esta ciudad mucha comida y que sabe que serían más de mil quinientas fanegas de maíz, y que luego hizo sembrar a todos los españoles y a cada uno daba de los indios que venían de paz para ayudarles a sembrar y que se sembró en el dicho mes de agosto que la pregunta dice y en el mes de enero adelante otra y vio que de ambas a dos sementeras se cogió muy poco maiz y que esta es la verdad.

b) El padre Alonzo Trueno -testigo en el que Baez se basó mayormente- amplió la información sobre los cultivos consumidos:

A las veinte preguntas dijo que lo que sabe de esta pregunta es que se recogió poca cantidad de maíz, frisoles y zapallos e quínoa y que se sembró por el mes de agosto como la pregunta dice y septiembre y octubre y otra sementera por el mes de enero y para hacer las dichas sementeras el dicho capitán Juan Núñez del Prado dio indios a todos para que las hiciesen de los que venían de paz y sabe que de la primera sementera se cogió poco maíz y de la postrera ninguno, porque se comió todo y enviolo por tener necesidad de comida aún por podrirse de las muchas aguas que había.

c) Juan Núñez de Guevara testificó que:

A las veinte pregunta dijo que sabe que en el tiempo contenido en la dicha pregunta se metió en esta ciudad mucho maíz pero que no sabe la cantidad de fanegas que serían y así mismo sabe que en el dicho mes de agosto el dicho capitán Juan Núñez del Prado mandó que sembrasen todos y les dio indios de los que habían venido de paz para ayudarles a hacer sus sementeras y vio que en el dicho mes de enero adelante se hizo otra sementera y de la primera se cogió muy poco maíz y de la segunda no nada, porque se cogió muy poco en choclo y esto sabe de esta pregunta.

d) Por último, para cerrar con los testimonios, incluimos el de Rodrigo Palos, quien

Dijo que lo que de esta pregunta sabe es que vio que se metió en esta ciudad en el tiempo que la pregunta dice mucha cantidad de comida (...) e así mismo se hizo la otra sementera por el mes de enero y sabe que de la primera (...) se cogió poco maíz y de la segunda no ninguno, porque se podría con las aguas y lo comieron los yancucnas antes de maduro. 
Aun así, a pesar de la evidencia negativa para la ciudad de El Barco, consideramos factible que los cereales y frutales alóctonos ingresaran al NOA en la década de 1550. La fundación de Santiago del Estero en 1553 sería un buen motivo para pensar que Francisco de Aguirre, quien provenía de Chile, introdujera semillas de trigo, cebada y frutales. A pesar de todo, las crónicas no resultan iluminadoras al respecto, por lo cual nos deja abierta la duda. Paul Groussac afirma que Aguirre, apenas llega a territorio tucumano, se da cuenta del gran desabastecimiento de la población y envía inmediatamente una expedición a Chile que regresa en mayo de 1553 con "semillas, plantas, herramientas, además de algunos labradores y menesteres". No dejan de ser muy interesantes estos datos, pero el autor no explicita la fuente de su información y por momentos parece que se trata solo de una interpretación propia debida a los errores en los que cae, como ya lo remarcara Manuel Lizondo Borda ${ }^{7}$.

Diferente para nosotros es el testimonio del procurador del cabildo de Santiago del Estero, Alonso Abad, quién ha dejado importante información reveladora para continuar con el análisis. Ha quedado bien establecido que, luego de que Francisco de Aguirre fundara Santiago del Estero en 1553, se retira a Chile al año siguiente dejando a cargo a Gregorio de Bazán. Debido al desamparo de la ciudad, en gran medida por la resistencia indígena, los comestibles y elementos básicos para la subsistencia comenzaron a escasear, por lo cual Bazán decide, a finales de 1555, enviar a Chile cinco soldados en busca de bastimentos y un sacerdote. Los encomendados para esta empresa fueron: Rodrigo de Quiroga, Bartolomé Mansilla, Nicolás de Garnica, Pedro de Cáceres y Hernán Mejía de Miraval, quienes regresan a principios de 1556 trayendo al padre Juan Cidrón y además cantidad de objetos y productos de primera necesidad, fundamentales para la subsistencia de dicha gente, de cuyos costos se hace cargo el gobernador Aguirre. Esto es lo que Abad textualmente afirma de tal suceso:

Después de muchos meses trajeron sacerdotes que les administró y entonces trajeron algunas semillas de trigo, cebada y otras cosas de Castilla y algodón (...) y otras cosas de ello de que ha redundado que se han podido sustentar hasta el día de hoy y esta ciudad a ido siempre en aumento con el trigo, cebada y maíz que se sembró y con los árboles higuera, viñas y otras cosas que se pusieron e plantaron ${ }^{8}$.

\footnotetext{
${ }^{7}$ Manuel Lizondo Borda, Historia de la Gobernación del Tucumán (Siglo XVI), (Buenos Aires: Publicación de la Universidad de Tucumán, 1928): 136.

8 "Información levantada por el procurador del Cabildo de Santiago del Estero, Alonso Abad, entre los vecinos, destinada a demostrar los notables servicios por dicha ciudad en el descubrimiento y conquista de la comarca del Tucumán", en Levillier, "Gobernación del Tucumán”, 116-242.
} 
El cuestionario que sigue al relato de Abad contiene también -si bien de una manera no tan clara, por la extraña manera de construir las preguntas- algo de información relevante. La pregunta siete intenta averiguar:

Si saben que habiendo salido los dichos cinco españoles (...) y traído un sacerdote los españoles conquistadores asosegaron y se quietaron de tal manera que luego se dieron a sembrar los dichos algodones, trigo, maíz, cebada y otras cosas, plantando viñas, higueras y otros árboles frutales de castilla 9 .

Los testigos coinciden totalmente con la pregunta. Responden, por ejemplo, "a la septima pregunta dijo que sabe y vio este testigo que después de venido de Chile el sacerdote, todos los vecinos de esta ciudad recibieron mucho contento de ello (...) y fueron sembrando muchas semillas y algodón, trigo y maíz e plantas de Castilla".

Queremos remarcar ahora la importancia de esta información, ya que resulta sumamente ilustrativa para comenzar a descubrir los tipos de productos que desde Chile estaban llegando al Tucumán colonial. Además hay que tener en cuenta que estos cereales se cultivaban en Chile desde las primeras poblaciones españolas asentadas allí ya en 1542 y que su producción era tan grande que en las primeras épocas sus ciudades exportaban trigo hacia Perú, casi siempre deficitario en razón de las enormes demandas que generaba el trabajo minero ${ }^{10}$. Además, para este momento, no solo en las poblaciones hispanas se manipulaban dichos productos. Se tienen referencias relativas a la fundación de Mendoza, donde se menciona que los indios huarpes ya cultivaban trigo y cebada al momento del arribo de la expedición de Pedro del Castillo en 1561. Se considera -y así lo demuestran varios documentos- que estos indígenas habrían obtenido los cultivos por intercambio con poblaciones españolas en Chile durante la gobernación de Valdivia ${ }^{11}$. Por otro lado, es mucho más importante para este trabajo el testimonio que nos ha dejado Pedro Sotelo de Narváez acerca de los "indios de guerra" del valle Calchaquí: "tienen partes fragosísimas donde siembran. Es tierra muy abundante de papas papas son como turnas de tierra, que se siembran- maíz, frisoles y quínoa, zapallo, trigo y cebada y todas legumbres, algarroba y chañar", ${ }^{\text {" }}$.

\footnotetext{
${ }^{9}$ Si bien la primera parte de la oración es estructuralmente similar a la reproducida por Báez y que citáramos previamente, el resto no concuerda, como pudimos constatar, y por ello decidimos incluir ambos testimonios.

${ }^{10}$ Baudot, La vida cotidiana.

${ }^{11}$ Báez, "La primera colonia".

${ }^{12}$ P. Sotelo de Narváez, "Relación de las provincias del Tucumán que dio Pedro Sotelo Narváez, vecino de aquellas provincias, al muy ilustre señor Licenciado Cepeda, Presidente desta Real Audiencia de La Plata”, 1583, en E. Berberian, Crónicas del Tucumán. Siglo XVI (Comechingonia, Argentina: UNC, 1987). Subrayado del autor.
} 
Independientemente de esta fuente, la investigadora Ana Lorandi confirma que los indígenas no conquistados del Tucumán habrían incorporado el trigo y la cebada en sus cultivos. Más interesante aún es la interpretación que realiza sobre el tema, desestimando que estos elementos hayan tenido un impacto significativo en estas culturas $^{13}$.

Una referencia mucho más precisa para la introducción de los cereales aparece en Bartolomé de Las Casas quien afirma que Pérez de Zurita portaba granos de trigo durante la expedición que resultara en la fundación de Londres de Quimivil en 1558 , la cual partió un año antes de La Serena, donde esta especie se consolidó desde su fundación en $1543^{14}$. Adán Quiroga hace una recopilación de numerosos cronistas, entre ellos, un tal Herrera, que con su testimonio ilustra parte de la cuestión relativa a las plantaciones de árboles frutales en la primera Londres:

El otro lugar, dicen que había de estar a donde estuvo un pueblo, llamado Londres, en el Camino de Tucumán, de la gobernación de Chile, se despobló por la poca gente que había, es el Valle de Quinmibil, es tierra fértil para sembrar trigo, maíz y cebada, y hubo buenas viñas, y arboledas, y de buen temple, y son todos los naturales diaguitas ${ }^{15}$.

Finalmente, estas referencias nos permiten componer un panorama distinto al que planteara Báez y dejar en claro que no puede confirmarse que el ingreso de especies cultivadas europeas se produjera desde el alto Perú $^{16}$, y que resulta más factible pensar que haya sido desde Chile; además, es probable que la ciudad del Barco de Ibatín no fuera el centro de dispersión de las mismas sino Santiago del Estero, que debe de haber jugado un rol trascendental en tal dispersión, como hemos podido reconocer en algunos documentos. La ayuda que brinda Santiago del Estero en la fundación de ciudades como Córdoba o Esteco queda evidenciada en las referencias al abastecimiento de bienes de todo tipo que salen de aquella ciudad. Incluso en las sucesivas fundaciones de Pérez de Zurita es fundamental el rol de Santiago del Estero. Alonzo Abad lo ha declarado:

... entró de Chile el capitán Juan Pérez de Zorita (...) poblándose otros muchos pueblos en nombre de su majestad que fue en los diaguitas en el valle de Quimivil la ciudad de Londres y en el valle calchaquí la ciudad de Córdova y en Tucumán (...) cañete para todas las cuales (...) salieron muchos de los primeros

${ }^{13}$ A. M. Lorandi, "El servicio personal como agente de desestructuración en el Tucumán colonial", Revista Andina (Cuzco, Perú), año 6, núm. 1 (1988): 135-173.

${ }_{14}$ A. Capparelli y R. Raffino, Arqueobotánica de El Shincal I: Tallos finos, frutos y semillas, vol. 3, Tawantinsuyu (Sydney, Australia: Brolga Press, 1997).

${ }^{15}$ A. Quiroga, Calchaquí, comentarios de actualización R. Raffino (Buenos Aires: TEA, 1992).

${ }^{16}$ El primer trigo llega al Perú aproximadamente en 1537 de la mano de Doña María Escobar, esposa de Diego de Chávez, que trajo desde España medio almud de granos. 
conquistadores que conquistaron y poblaron esta ciudad de Santiago con sus personas, armas y caballos a su costa y minción llevando ganado y otras cosas convenientes para las dichas conquistas y poblaciones ${ }^{17}$.

En referencia a la fundación de Esteco, el cuestionario menciona nuevamente la importancia de Santiago del Estero en cuanto a que "se saco de este ciudad muchos pertrechos, ganados y otras cosas para que se sustentase aquella ciudad"18. Con Córdoba se hace explicito el aporte de cultivos para el sustento de los primeros momentos de las entradas en la región y posterior fundación. En la probanza de mérito del conquistador y vecino funcionario de Córdoba, Lorenzo Suárez de Figueroa, destacamos la pregunta seis, que dice lo siguiente:

Y si saben que estando el dicho don Lorenzo Suárez de Figueroa en las dichas provincias del Tucumán en la de Santiago del Estero le dio y encargo don Jerónimo de Cabrera el descubrimiento de las provincias de lo comechingones y canavirones (...) y para ello llevó consigo cincuenta soldados (...) con armas, caballos y municiones y otras cosas necesarias para la jornada y a todos los dichos soldados los socorrió con comida de trigo, maíz y cebada ${ }^{19}$.

Ya finalizando el siglo XVI, y específicamente para la zona de Catamarca, algunas crónicas y documentos oficiales nos permiten continuar con el itinerario histórico de estos cultivos. Nuevamente, Pedro Sotelo de Narváez, en su "Relación de las provincias de Tucumán", describe sucintamente para 1583 el gran potencial agrícola de la zona de Londres, sin dejar de mencionar cultivos tanto autóctonos como del Viejo Mundo: "trigo y maíz, cebada y mucha cantidad de frisoles y dáse todo lo de Castilla" ${ }^{20}$. Este mismo cronista detalla minuciosamente los tipos de frutales que se estaban cultivando para este momento en Santiago del Estero, y describe que "los españoles y ellos tienen ahora frutas de España, que se han plantado; viñas de que se cogen muchas uvas y vino, duraznos, higos, melones, membrillos, manzanas, granadas; perales y ciruelos aún no han dado fruta; hay limas y naranjas" ${ }^{\prime 2}$. Con esto podemos evidenciar la gran variedad de frutales europeos que ya para fines del siglo se afianzaban en estas tierras, destacando que generalmente no es apreciada tal diversidad cuando en los escritos de la época queda subsumida bajo el rótulo "frutales de Castilla" o "todo lo de Castilla".

\footnotetext{
17 “Información levantada", en Levillier, "Gobernación del Tucumán”.

${ }^{18}$ Ibídem.

19 "Información de los méritos y servicios de D. Lorenzo Suárez de Figueroa, hecho en la conquista y población de las provincias de Tucumán con D. Jerónimo Luis de Cabrera y Gonzalo de Abreu, y especialmente en el cargo de capitán y justicia mayor en Córdoba, de la Nueva Andalucía", en Levillier, "Gobernación del Tucumán".

${ }^{20}$ Sotelo de Narváez, "Relación de las provincias".

${ }^{21}$ Ibídem.
} 
Mención aparte, en relación con la producción triguera merece Córdoba de la Nueva Andalucía, luego de su fundación en 1573. Es notable el exponencial incremento que sufrió esta ciudad con respecto a la producción de harina desde sus primeros años, y que continuaría en ascenso hasta aproximadamente 1625, cuando comenzó lentamente su ocaso. Para darnos una idea, ya en 1579 se instala el primer molino en la ciudad y para el alba del nuevo siglo eran mas de cinco los allí construidos. El aumento de estos medios de producción es fiel indicador de la importancia de la producción harinera en la región, cuyos enormes excedentes eran colocados en regiones de colonias lusitanas como Brasil y Angola. Los cultivos primero se realizarían en la región noroeste de la provincia en coincidencia con la dispersión de los grupos comechingones ${ }^{22}$ de economía con fuertes componentes agrícolas antes de la llegada española. Con posterioridad, ya en el siglo XVII, se expandirían los campos de cultivo hacia las llanuras del centro y sur de la provincia. Este fenómeno extraordinario lleva al investigador Félix Torres a postular un "ciclo de la harina" para Córdoba. En palabras del mismo autor, en 1606 Córdoba posee una estructura productiva en relación con la harina con un relativamente alto nivel de especialización y elaboración de productos derivados. Las causas de esto podrían encontrarse en una mayor concentración de la mano de obra para estos tipos de trabajo, así como también en la alta inversión en tecnología, como los molinos hidráulicos. De esta manera, se alcanzó un muy alto nivel tecnológico y productivo para su época, en comparación con las otras regiones también de reciente colonización ${ }^{23}$.

El trigo, la cebada, los frutales y otros cultivos comestibles del Viejo Mundo también se fueron incrementando a lo largo del siglo XVII. El padre Vázquez de Espinosa, quien recorriera las Indias Occidentales entre 1608 y 1622, nos deja el siguiente relato sobre nuestra zona de interés:

... la comarca de Londres es de maravilloso temple, de fertilísimas vegas y valles, en los cuales hay viñas y se da maíz y trigo en abundancia, con todas las frutas de España, con aumentar la población, se reducirían estas naciones a la fe y se comunicarían los reinos del Perú y Chile con más facilidad con los de Tucumán y Paraguay $^{24}$.

Es interesante destacar aquí que en la región de la actual Catamarca tenemos también una gran variedad de frutales y cereales de los traídos de España para

\footnotetext{
${ }^{22}$ No hace falta aclarar que tal relación no es azarosa, ya que la mano de obra perteneciente a las etnias comechingonias fue fundamental en este proceso.

${ }^{23}$ F. Torres, "Agricultura y conflictos en la Córdoba colonial", Todo es Historia (Buenos Aires), año 17, núm. 201 (1984): 38-58.

${ }^{24}$ A. Vázquez de Espinosa, Compendio y descripción de las Indias Occidentales, Crónicas de América 68b (1628; reimpresión, Madrid: Editorial Historia 16, 1992).
} 
principios del siglo XVII, que luego se convertirían en el eje de la agricultura colonial.

\section{Los cultivos europeos en la vida aborigen}

Poco se ha escrito sobre la introducción del trigo, la cebada y otros cultivos en las tierras del actual NOA en los primeros momentos de la conquista y colonización española. Menos aún sobre su introducción, producción y consumo por parte de los distintos grupos aborígenes que habitaban esta amplia región. En general, se acepta que los cereales y frutales del Viejo Mundo llegaron al NOA con las primeras fundaciones, luego de 1550, y que su cultivo prosperó rápidamente y fue aceptado pasivamente por los indígenas, poco a poco, en su dieta y costumbres. Así, se han pasado por alto o jamás se han tenido en cuenta numerosos factores que actúan al momento de la introducción de un elemento cultural desconocido o foráneo y que, consecuentemente, podrían determinar su aceptación o rechazo. Pongamos un ejemplo conocido y estudiado: la introducción de maíz en Europa. Llegado en los primeros viajes de Colón, fue en los siglos XVI y XVII muy escasamente aceptado en el Viejo Mundo, y transcurrirían varias décadas desde hasta que fuera cultivado en algunas regiones de España y Portugal, principalmente con fines forrajeros. Los escritos de carácter peyorativo son fáciles de hallar y citaremos uno que encontramos ilustrador de este caso. El naturalista inglés M. Gerardé opinaba que

... el trigo turco ${ }^{25}$ nutre mucho menos que el trigo, centeno, cebada o avena. El pan que de él se hace (...) es tan duro y seco como una galleta (...), causa indigestión violenta y rinde poca o ninguna nutrición al cuerpo (...). Todavía no tenemos prueba cierta o experiencia respecto a la virtud de este grano, aunque los indios bárbaros que no conocen nada mejor, limitados a hacer una virtud de la necesidad, piensan que es un buen alimento ${ }^{26}$.

Las ventajas del maíz para la alimentación humana no serán reconocidas sino hasta bien entrado el siglo XVIII. Es necesario apuntar que muchas veces la introducción de un elemento cultural atraviesa un proceso que necesariamente debe sortear numerosos obstáculos, como el prejuicio, la desconfianza, el conservadurismo o el rechazo al cambio, aspectos que tornan dificultosa su asimilación por el solo hecho de aparecer en escena.

Cuando profundizamos en los trabajos históricos sobre la sociedad y economía del Tucumán colonial, la mayoría concuerda en que el trigo, la cebada, la vid y los

${ }^{25}$ Trigo turco es el nombre con que se conocía al maíz fuera de España - donde, a su vez, se lo llamaba grano de Indias-, debido a que su introducción no fue directamente desde la península Ibérica sino desde Turquía.

${ }^{26}$ Arturo Warman, La historia de un bastardo, maíz y capitalismo (México: Fondo de Cultura Económica, 1974). 
otros cultivos eran sembrados y cosechados por los mismos aborígenes como parte del servicio personal, la mita o cualquier otro tributo impuesto por los invasores. Desde temprano se intentó adiestrar a la población nativa en las técnicas necesarias para dicha producción ${ }^{27} \mathrm{y}$ abastecer de esta forma las demandas de las ciudades y, en muchos, casos de exportación al interior del virreinato. Pero el solo hecho de la manipulación de semillas y plantas del Viejo Continente no es motivo suficiente ni puede asegurarnos el consumo cotidiano o la introducción en la dieta aborigen de estos productos. Los distintos autores consultados también coinciden en un punto que resultara crucial para nosotros: los aborígenes no consumían trigo y cebada, o raramente lo hacían, y esto por motivos extraordinarios ${ }^{28}$. Pero también podemos hallar otros ejemplos, como el presentado por Gabriela Sica en su trabajo sobre encomiendas y tributos del siglo XVII en San Francisco de Paipaya, Jujuy, donde describe que los indios cultivaron en su chacra de carácter comunal maíz, trigo, cebada y legumbres "aparentemente" para su consumo ${ }^{29}$.

El problema que se nos presenta aquí es que el fenómeno de la adopción y consumo de cultivos europeos ha sido exiguamente estudiado y es raro hallar referencias más específicas que superen la mera aproximación superficial. Tratando de superar este inconveniente, intentaremos ahora trabajar con diversos cuerpos de evidencias, aunque escasas, con el objetivo puesto en la interrelación con otros factores socioculturales que conformaban la dinámica del contexto social colonial del noroeste Argentino en el período temprano de la conquista.

En primera instancia, y avanzando un poco más en lo expuesto arriba, observamos que autores como G. Baudot -que han tratado el fenómeno de la vida cotidiana en la América en el período de Felipe II- generalizan hasta el extremo de aseverar que "visiblemente los agricultores indígenas no querían cultivar trigo, no dominaban la técnica de su cultivo $\mathrm{y}$, aferrados a su maíz y a sus herramientas rudimentarias, obtenían resultados menos que mediocres ${ }^{\$ 30}$. Por lo mismo, intenta confirmar su

\footnotetext{
${ }^{27}$ Cabe aclarar que no nos referimos a las técnicas para la práctica agrícola en sí, ya que muchas de estas comunidades las habían adquirido siglos antes, sino a los elementos de una agricultura de características europeas.

${ }^{28}$ Sobre este tema, véase Lorandi, "El servicio personal"; Baudot, La vida cotidiana; G. Doucet, "Los réditos de Quilpo. Funcionamiento de una encomienda cordobesa a fines del siglo XVI (1595-1598)", Jahrbuch für Geschichte von Staat, Wirtschaft und Gesselschaft Lateinamerikas (Colonia, Alemania), s. n. (1986): 63-119; C. López de Albornoz y A. M. Bascari, "Pueblos de indios de Colalao y Tolombón: Identidad colectiva y articulación étnica y social (siglos XVII-XIX)”, Humanitas (Tucumán, Argentina), 27 (1998): 63-119.

${ }^{29}$ Gabriela Sica, "Vivir en una chacra de españoles: encomienda, tierra y tributo en el pueblo de San Francisco de Paipaya, Jujuy, siglo XVII", en Los pueblos de indios del Tucumán colonial, comp. J. Farberman y R. Gil Montero (Jujuy, Argentina: Ediunju; UNQ, 2002).

${ }^{30}$ Baudot, La vida cotidiana, 170.
} 
punto de vista con un ejemplo más que certero: en 1559, el virrey de México impuso tributo a los indígenas en trigo para que se habituaran a él, pero dos años después debió desistir al comprobar que estos compraban el necesario para pagarlo. En Perú sucedía lo mismo en cuanto a su consumo. El registro del padre Carmelita Vázquez de Espinosa sobre la comida que se preparaba a los indios en el hospital de Santa Ana de Lima a comienzos del siglo XVII ayuda a sustentar las aseveraciones de Baudot con el siguiente comentario: "y como los indios están acostumbrados a sus comidas de maíz y yerbezuelas sazonadas con ají o pimiento, se les adereza a su modo" ${ }^{131}$.

El cronista Francisco López de Gómara va un poco más lejos y expone las razones por las cuales los indios no cambian el maíz por el trigo:

Los motivos que dan son grandes y son los siguientes: que están acostumbrados a este pan, y se hallan bien con él; que el maíz les sirve de pan y vino; que multiplica más que el trigo; que se cría con menos peligro que el trigo, así del agua y sol como de las bestias; que se hace más sin trabajo, pues un solo hombre siembra y recoge mas maíz que un hombre y dos bestias trigo ${ }^{32}$.

En líneas muy generales, todo pareciera apuntar a la consideración de que el consumo habitual de productos europeos por parte de los aborígenes americanos fue rechazado de plano. Pero, ies posible aseverar esto para todos los bienes introducidos, vale decir cultivos, animales o vestimenta por ejemplo? Además, ¿sucedió lo mismo en cada rincón de las colonias españolas a manera de proceso general y absoluto?

Para intentar un acercamiento a la última pregunta, vayamos a los casos específicos del antiguo Tucumán. En una revisión del trabajo de Judith Farberman ${ }^{33}$ sobre la visita del oidor Luján de Vargas a Santiago del Estero hacia fines del siglo XVII podemos intentar recolectar ciertas pistas de la relación de los indígenas encomendados y los cultivos de trigo que ellos mismos producían. En tres oportunidades aparecen transcripciones textuales de personas involucradas en los procesos de la visita - dos de indios y una respuesta del encomendero-, que reproduciremos a continuación. Por una parte, los indios de Sabagasta respondieron, en cuanto a su obligación de tributo, que eran forzados a trabajar por su encomendero "en la sementera de trigo que han hecho con más de un almud de maíz en las tierras de dicho su pueblo, siendo de seis fanegas la siembra de trigo, lo

\footnotetext{
${ }^{31}$ Vázquez de Espinoza, Compendio y descripción.

${ }^{32}$ Francisco López de Gomara, Historia general de las Indias, ed. German Vázquez (1552; reimpresión, Madrid: Historia 16, 1987).

${ }^{33}$ J. Farberman, "Feudatarios y tributarios a fines del siglo XVII. Tierra, tributo y servicio personal en la visita de Luján de Vargas a Santiago del Estero (1693)", en Los pueblos de indios del Tucumán colonial.
} 
cual ha sido más de fuerza que de voluntad". Además, puede destacarse en estas entrevistas que solo se continuaba con una práctica que desde hacía años se llevaba adelante en el lugar, y continuamente se obligaba a los indios a cultivar "todos los años sementeras de trigo sin darles paga ni porción alguna de lo que [se] cogía de las sementeras" ${ }^{34}$.

Por otro lado, a la segunda pregunta del cuestionario, los indios de Alagastine respondieron que "el tributo se les cobra por el encomendero en servicio personal que le hacen en la sementera que hace en su estancia cercana al dicho su pueblo y que en las tierras de los indios les hizo sembrar dos sementeras y de las cosechas que ha cogido dicho encomendero no les ha dado nada del dicho trigo". Por último, el encomendero de este pueblo, Joseph de Medina, responde que "de las sementeras de trigo no han percibido los dichos indios nada, que les a pagado a dos reales de jornal por día a los que han trabajado, que son dos o tres indios" ${ }^{\text {"35. }}$.

De este último caso hay algo muy importante para rescatar, tanto en lo que respondió una como otra parte: los indígenas no percibieron nada del trigo que fueron obligados a cultivar. En el caso de Sabagasta sucede lo mismo, además con una confirmación de la prolongación de esta práctica en el tiempo. Inmediatamente surge la pregunta ¿cuáles fueron los alimentos que permitieron la subsistencia de estos indígenas denunciantes, al menos para el momento en que nada recibían de sus cosechas? Por lo visto, no era el trigo que cultivaban para el encomendero. Pero ¿era esta la totalidad de las cosechas producidas? Por lo que se desprende de estos testimonios pareciera que no. Esta aseveración surge a partir del caso de Sabagasta donde el encomendero Juan de Trejo asegura poseer tierras cercanas a las de los indios donde hizo cultivar su trigo, producción que ocasionara la disputa. Los indígenas afirman lo contrario, pero todo parece sugerir que solo está en disputa una porción del terreno total ocupado por los indios, o sea, las tierras que el encomendero considera como aledañas al asentamiento y, por lo tanto, de su propiedad y que los indígenas consideraban como propias. ¿Qué se cultivaba en el resto del terreno de los pueblos de indios? Por el momento no contamos con una respuesta directa. Puede arrojarnos algo de luz cierta concepción de los indígenas de las llanuras tucumano-santiagueña plasmada en un comentario del gobernador Alonso de Ribera donde el maíz era considerado por ellos aún como "mejor alimento de todos y tienen ellos por mejor sustento y verdaderamente lo es" Alonso de Barzana, padre jesuita cuya estadía en el Tucumán se remonta a la

\footnotetext{
${ }^{34}$ Ibídem.

${ }^{35}$ Ibídem.

36 "Carta del gobernador Rivera al Rey", Archivo General de Indias (Sevilla), Charcas 26, ramo 8, núm. 64, fol. 536. Citado en, La expansión de los ganados europeos: cambios en la economía y cultura material de las poblaciones indígenas de San Miguel de Tucumán (1600-1620). Actas del XII Congreso Nacional de Arqueología Argentina, Estela Noli (La Plata: UNLP, 1999).
} 
segunda mitad del siglo XVI, nos deja un relato muy ilustrativo, aunque lamentablemente poco conclusivo, de las costumbres culinarias de las "naciones" del Tucumán:

El modo de vivir de todas estas naciones [diaguitas] es el ser labradores. Sus ordinarias comidas son el maíz, lo cual siembran en mucha abundancia; también se sustentan de grandísima suma de algarroba, la cual cogen por los campos todos [los] años al tiempo que madura y hacen de ella grandes depósitos; y cuando no llueve para coger maíz [o] el río no sale de madre para poder regar la tierra, pasan sus necesidades con esta algarroba ${ }^{37}$.

Decimos poco conclusivo porque en este relato no es posible diferenciar si se trata de indios sometidos o aún de guerra, o sea, en libertad, lo cual cambiaría mucho el valor de la información del documento. Si fuesen indios "gentiles", esta aseveración sería de esperar, pero si se trata de individuos sometidos y encomendados, nos hablaría de una continuidad de lo propio en sus cultivos de subsistencia, aún cargando con el peso desestructurante, desde el punto de vista cultural, de la imposición colonizadora.

A pesar de este problema, la última referencia nos empuja a ver un fenómeno fundamental en relación con la subsistencia de los grupos del NOA en cuestión, que muy bien podría ajustarse a la idea de que cultivos como el trigo y la cebada escapaban a la dieta aborigen. Los trabajos de investigación etnohistórica de Estela Noli nos abren la puerta para considerar la importancia de los productos de recolección como la algarroba, la miel y las langostas ${ }^{38}$. Según cálculos estimativos, es altamente probable que el $50 \%$ de la dieta fuera cubierta por estos productos de la naturaleza, mientras que el resto era completado por productos agrícolas. Consideramos, además, que lo más importante de este trabajo es el postulado de que luego de las obligaciones del trabajo encomendil, los aborígenes paulatinamente hicieron retroceder el porcentaje de la dieta destinado a productos agrícolas a favor de los recolectados. O sea, que la recolección, sobre todo de algarroba, jugó un papel trascendental en la reproducción de las condiciones materiales de existencia de los grupos nativos para este momento. Ahora bien, las estrategias de subsistencia de este tipo establecidas por diferentes etnias del NOA ¿tienen algún correlato con su supervivencia y cohesión como grupo social frente a

37 “Carta de P. Alonso de Barzana, de la compañía de Jesús, al P. Juan Sebastián, su provincial. Fecha en la Asunción del Paraguay a 8 de Setiembre de 1594”, en E. Berberian, Crónicas del Tucumán. Siglo XVI.

${ }^{38}$ Estela Noli, "La recolección en la economía de subsistencia de las poblaciones indígenas: una aproximación a través de las fuentes coloniales (piedemonte y llanura tucumanosantiagueña). Gobernación del Tucumán”, en C. A. Aschero, M. A. Korstanje y P. M. Vuoto, eds., En los tres reinos: prácticas de recolección en el cono sud de América (Tucumán: UNT; Magna Publicaciones, 1999). 
los embates desestructurantes impuestos por el colonizador? Es altamente probable que sí, y así lo han demostrado trabajos enfocados en el fenómeno relacionado con las "juntas y borracheras" 39 , donde queda bien claro el papel de la algarroba y sus derivados (como la aloja) en la resistencia y supervivencias de prácticas ancestrales de ritos y socialización.

Por otro lado, hay que destacar que los mismos españoles alentaron la práctica de recolección de algarroba ante la ventaja que producía para sus propios intereses. En efecto, de esta manera la mano de obra podía autosustentarse una gran parte del año con productos que no tenían salida en los mercados del virreinato, como Potosí, o inclusive en regiones más distantes, como Brasil o África ${ }^{40}$. Además, no hay que olvidar que la algarroba se utilizaba también para el engorde del ganado y muchas veces para el pago de sayapayas e indios de mita ${ }^{41}$. Es por ello que en la ciudad de Santiago del Estero parte del tributo muchas veces era pagado con este producto, con lo que se generaba un circuito económico interno y local que otorgaba grandes beneficios a los españoles. Por este hecho, las ordenanzas de Abreu y luego las de Alfaro dedicaron un espacio importante a la reglamentación de este tipo de prácticas.

\section{Formas posibles de obtención de los cultivos foráneos}

En la introducción ya hacíamos mención a la pregunta sobre cómo obtendrían los aborígenes productos tales como el trigo, cebada o frutales, en caso que se alimentaran de ellos. Se nos presentan al menos tres situaciones donde este fenómeno podría haber ocurrido analizando los distintos mecanismos de relaciones económicas entre encomenderos y encomendados:

a) La primera, y en relación con las mitas obligatorias, los indígenas en muchos casos podían ofrecerse a los particulares e incluso a sus propios encomenderos descontándolo del tributo. Si existía una diferencia entre este último y el jornal, los encomenderos debían pagarla. Lo mismo ocurría en el caso de los particulares. Esta diferencia, denominada "demasía en tasa", debía ser saldada en los géneros y especies que los indígenas solicitaren, según se estipulara en las ordenanzas de

\footnotetext{
39 Isabel Castro Olañeta, "Recuperar las continuidades y transformaciones: las 'juntas' y borracheras de los indios de Quilino y su participación en la justicia colonial", en Farberman, Los pueblos de indios; M. M. Arana, "El tiempo de la algarroba", en Aschero, En los tres reinos.

${ }^{40}$ Este sí era el caso del trigo y la cebada, como constatamos para Córdoba, de cuyo circuito incluso el maíz participó muchas veces.

${ }^{41}$ Noli, "La recolección en la economía".
} 
Alfaro $^{42}$. Este punto es importante para nosotros porque cabe la posibilidad de que se pagara en productos alimenticios y, entre estos, los de origen europeo. Sin embargo, es muy frecuente encontrar referencias a las formas de pago, en la mayor parte de las cuales los textiles ocupan el lugar principal, y cuando productos alimenticios forman parte de la transacción, sucede que los derivados de la recolección, como la algarroba, son los mencionados en las crónicas, según pudimos constatar en el apartado previo. Incluso en los contratos concertados con las mujeres indias, estaba estipulado en "una manta, una lliclla y una faja y una camisa todo nuevo" 43 por un año de trabajo. Por esta participación, fundamental en la economía local, los textiles eran designados en aquel momento como "moneda de la tierra". Sin embargo, en el trabajo de Doucet sobre las encomiendas de Quilpo en Córdoba, sobresale un caso en donde el administrador Luis de Abreu, refiriéndose a la chacra de Chibaja, sostiene que luego de la cosecha de trigo, diez fanegas de la misma "se dieron y repartieron a los indios del dicho menor [el titular de la encomienda] que lo ayudaron a coger" ${ }^{24}$. ¿Lo consumieron, lo vendieron o lo intercambiaron? Es difícil conocer la respuesta, pero en el punto siguiente trataremos de avanzar un poco sobre la segunda posibilidad.

b) La obligación de alimentar a los indígenas de encomienda o en servicio personal en las estancias o residencias de españoles es otra forma de verificar el consumo de cultivos europeos en la dieta aborigen. Esto es una muy buena posibilidad y se hace necesario analizarla teniendo en cuenta su variabilidad intrínseca, o sea, los indígenas que acudían a la mita, por un lado, y los que residían permanentemente con los españoles, por el otro. Estos últimos los analizaremos con más detenimiento más adelante. En cuanto a las mitas de trabajo temporal, ya vimos la importancia de la algarroba como parte de la alimentación de estos grupos. Por otro lado, una referencia del fundador de La Rioja, Ramírez de Velasco, es sugerente con respecto a las formas de reclutamiento de la mano de obra y su manutención: "los traen [a los indios] de a 10, 15 o 20 por vez, por quince días por tanda", viniendo a veces "desde treinta leguas cargados con la comida que han de comer todo el tiempo" ${ }^{\text {"45 }}$. Pero, a pesar de este caso -que no deja de demostrar que en muchas oportunidades deben de haber sido los mismos indios quienes se proveían de alimentos-, estaba estipulado que para la realización de obras públicas o el levantamiento de cosechas de españoles eran los beneficiarios de aquellas obras quienes debían proveer el sustento a los trabajadores. El caso de la donación de un terreno para el levantamiento de un convento en el valle de Catamarca por la señora María de Tapia puede mostrarnos tal situación para 1653:

\footnotetext{
${ }^{42}$ Roxana Boixados, "Los pueblos de indios de La Rioja colonial. Tierra, trabajo y tributo en el siglo XVII", en Farberman, Los pueblos de indios.

${ }^{43}$ Ibídem.

${ }^{44}$ Doucet, "Los réditos de Quilpo".

${ }^{45}$ Lorandi, "El servicio personal".
} 
... y más les dono un cáliz y patena de plata para la dicha casa y convento, y un ara, y vinagreras de plata, y una campanilla pequeña, con más veinte y cinco reses de ganado vacuno, y quince fanegas de trigo para el sustento de religiosos y obreros ${ }^{46}$.

A pesar de ser un muy sugerente testimonio, no podemos dejar de tener en cuenta que en ningún momento hace textual referencia a mano de obra indígena. Si bien es cierto que esta era muy importante para aquel momento, no descuidamos el hecho de que los esclavos negros también hacían este tipo de trabajos. Por otro lado, tenemos un muy buen testimonio hacia 1690 sobre la reparación de la iglesia de la ciudad de San Fernando, del valle de Catamarca, donde se decide convocar a los mitayos necesarios para la tarea y especificar cuáles serán las cosas que aportarán los vecinos más importantes. El señor Vicario donará "por dos meses el gasto de la carne de dicha obra (...) y dará cuatro fanegas de trigo para el sustento de la gente". Cabe aclarar que más adelante se especifica la calidad de indígenas de los mitayos ${ }^{47}$.

c) Otra posibilidad importante es la del cultivo en sus propias tierras dentro de la reducción. Ya hemos visto que luego de la visita de Alfaro quedaba estipulado como forma de tributo el entregar la mitad de tales cultivos al encomendero y que en muchas oportunidades este hacía plantar trigo. De hecho, el mecanismo de este sistema consistía en el aprovisionamiento, por parte del encomendero, de semillas, bueyes y aperos; los indígenas cultivaban, mantenían las cosechas y las levantaban. Como lo demuestra Boixados para La Rioja, "las chacras o sementeras de la comunidad se cultivaban previo acuerdo con el encomendero, quien disponía qué

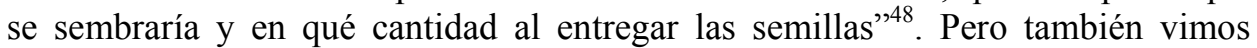
numerosísimos reclamos acerca de que los españoles se quedaban con la totalidad de la cosecha, cualquiera que fuera. Por otro lado, no hemos encontrado referencias directas al cultivo de productos europeos por voluntad de los indígenas. Pero, si este fuera el caso o se quedaran con una parte del trigo cultivado obligatoriamente, ¿podrían haberlo comerciado? López de Albornoz y Bascary ${ }^{49}$ afirman que tal era el destino de este tipo de producto en los pueblos de Colalao y Tolombón. Paralelamente, el estudio de la visita de Luján de Vargas nos demuestra que los indios participaban de los espacios mercantiles con productos agrícolas por

\footnotetext{
46 "Donación de tierras a lo P. P. Franciscanos por doña María de Tapia, viuda de León de Maidana. 4 de febrero de 1653", en A. Larrouy, Documentos relativos a Nuestra Señora del Valle y a Catamarca (Buenos Aires: Compañía Sudamericana de Billetes de Banco, 1915), 1: 181-202.

47 "La iglesia parroquial (del Valle Viejo). -Acuerdos del Cabildo-, 23 de octubre de 1690 ", en Larrouy, Documentos relativos. Subrayado del autor.

${ }^{48}$ Boixados, "Los pueblos de indios de La Rioja colonial".

${ }^{49}$ López de Albornoz, "Pueblos de indios de Colalao".
} 
intermedio de sus encomenderos ${ }^{50}$. De hecho, en la encomienda del pueblo de Guaco en La Rioja los indígenas declararon que la mitad de sus cultivos en las tierras comunales se la entregaron al encomendero para venderla. Como muy bien lo apunta la autora, aquí hay otro dato interesantísimo para rescatar, y es el hecho de que los indios de este pueblo no necesitaban de la cosecha de la chacra de comunidad para alimentarse, siendo las tierras comunales donde generalmente se cultivaba el trigo y la cebada.

Por lo anterior, podemos definir ya algunas cuestiones, a saber: en el caso de pagos por servicio prestado que excediera el tributo, donde estaba estipulado -aunque no se cumpliese- los indígenas decidían en qué productos los realizaban; generalmente, los textiles iban en primer lugar, y cuando productos comestibles eran parte de la transacción, las referencias a la algarroba son las más abundantes y comunes. Para el caso de la alimentación de los mitayos mientras realizaban los trabajos obligatorios, encontramos la interesante situación de que generalmente los mismos españoles aportaban la cantidad de granos necesaria y que el trigo aparece como el principal de estos aportes. Este debe de haber sido un excelente escenario donde marcar la relación de consumo entre los indígenas y los cultivos extranjeros, más por obligación -no eran ellos quienes decidían qué comer o no- que por propia decisión. En el tercer punto, podemos establecer que el cultivo de trigo y cebada sí se realizaba en las tierras comunales indígenas, pero esto era más que nada por orden de su encomendero, quien se quedaba la mayor parte de las veces con lo producido, no hallándose referencias a su cultivo voluntario por parte de los indios ni a su consumo obligado.

\section{Diferenciación dentro de la sociedad aborigen}

Indudablemente, creemos que el análisis de las costumbres alimentarias indígenas de los primeros siglos de la colonia no puede dejar de reconocer y tomar en consideración las características de la organización social de aquel entonces. Con esto queremos hacer referencia a las diferencias mismas dentro de los grupos indígenas luego de las transformaciones radicales de su organización previa. Ello obviamente está en relación directa con la imposición del nuevo orden económicosocial que implicó la conquista española. Diferenciación esta que se establecerá sobre todo para organizar y categorizar la fuerza de trabajo. Pongamos el caso de los indios de servicio y los indios de reducción o habitantes de los pueblos de indios. Los primeros residían generalmente en la morada del encomendero o del encargado cumpliendo tareas de servidumbre doméstica. Los segundos, como es bien sabido, eran el producto de la práctica de la legislación toledana $\mathrm{u}$ organización de las "dos repúblicas" aplicada en el Tucumán -si bien no de manera completa- a partir de 1612 con las ordenanzas de Alfaro. Cuando profundizamos

${ }^{50}$ Boixados, "Los pueblos de indios de La Rioja colonial". 
en el análisis de las costumbres de uno y otro grupo, se hace significativo el reconocimiento de que la influencia española lógicamente fue mayor entre los indios de servicio, por el hecho de haber sido separados de su comunidad y permanecer constantemente bajo el control de quienes, en mayor o menor medida, buscaban la transformación cultural de sus vasallos. Como para el caso de los indios de reducción ya hemos hablado suficiente, nos centremos ahora en el otro caso, los de servicio, muchas veces considerados yanaconas. Esta problemática está claramente observada en el análisis de "Los réditos de Quilpo",51, donde podemos encontrar referencias como la de los gastos en comida para el "menor encomendero y sus indios de servicio" contabilizada por el esposo de su madre, el administrador de dicha encomienda, Luis de Abreu. Allí consignó, para el año 1596, que el trigo de la cosecha de esa temporada se iba "gastando en el sustento de dichos menores y su casa y servicio, porque gastaron de ello hasta que se cojó el maíz, que fueron tres meses". Pero más significativo aún para nosotros es el hecho de que la cosecha de maíz aparentemente se gastaba solo en "los dichos indios y servicio del dicho menor". ¿Quiere decir esto que el maíz era destinado solo a los indígenas? De importancia fundamental es la afirmación apuntada por Doucet, que ya utilizáramos anteriormente, acerca de que "no parece ocioso señalar cómo estos textos sugieren que, normalmente, el trigo se destinaba al consumo de los españoles y el maíz al de los naturales" ${ }^{, 2}$. Sin embargo, todo parece indicar que el carácter de los alimentos quedaba supeditado a las decisiones del señor Abreu. Por lo tanto, no dejamos de preguntarnos por qué, en un espacio dominado completamente por concepciones y cosmovisiones de origen ibérico, los indios continuaban alimentándose como pudieran decidir. ¿Es que acaso tendría en cuenta el administrador los gustos propios de los sirvientes o habría algún motivo de conveniencia? Para considerar este último caso, habría que indagar en los costos de cada una de ambas situaciones o relacionarlos con la calidad y cantidad del tributo agrícola recibido, información esta que no poseemos hasta este momento.

Cambiando completamente de escenario abordaremos otro aspecto de la diversidad aborigen del Tucumán colonial. Analizando otra carta del gobernador Alonso de Ribera, de 1608, encontramos la siguiente afirmación; "y por las causas dichas ha sido el año trabajoso de comida aunque ha habido mucha algarroba que para lo que es los indios [de Santiago del Estero] suple la falta de trigo y maíz" "53. Al tratar de dilucidar el sentido de esta oración, realmente no queda muy claro si los indígenas consumían corrientemente trigo y maíz y la algarroba era para los casos de necesidad o, como ya habíamos visto, previamente se había vuelto un componente fundamental de su dieta, de manera que, por lo tanto, la escasez de cereales no

\footnotetext{
${ }^{51}$ Doucet, "Los réditos de Quilpo".

${ }^{52}$ Ibídem, 108.

53 "Carta del Gobernador Alonso de Rivero a S. M. 11de febrero de 1608”, en Raúl Argerich, Historia de Londres (Catamarca: Municipalidad de Londres, 2000).
} 
causaba en ellos ningún impacto. Pero, quedándonos con la posibilidad de que el gobernador Ribera aluda a que los indios consumían tanto trigo como maíz, aún queda, en nuestra opinión, un fenómeno muy interesante por analizar. Los aborígenes de la región de Santiago del Estero fueron categorizados por los españoles bajo el rótulo de juríes, pero esto ocultaba una gran diversidad étnica dentro de un conjunto extraordinariamente heterogéneo. Este grupo estaba conformado, a grandes rasgos, básicamente por dos tipos distintivos: los tonocoté, cultivadores y sedentarios o semisedentarios, y los lules, más relacionados con los grupos chaqueños $\mathrm{y}$ organizados alrededor de una subsistencia cazadorarecolectara. De ambos grupos fueron capturados y reducidos individuos y grupos enteros para ser repartidos y cumplir con la encomienda. La pregunta que nos hacemos aquí es por la manera como operó la nueva organización social impuesta sobre todo a los grupos lules nómades. Sabemos que a los grupos agricultores o cultivadores no les resultaba ajena la nueva estructura de subsistencia -la producción de alimentos-y que, de hecho, cultivos propios, como el maíz, el zapallo o el ají, se insertaron en esta sin problemas. Pero para los grupos cazadores-recolectores estos productos no les eran extraños y, obviamente, más el trigo u otro alimento europeo. Por lo tanto, la nueva situación forzosa debe de haber provocado una transformación radical en su antigua forma de vida que los obligó a cultivar la tierra y consumir productos, ya fueran de origen americano o europeo, que no formaban parte de su dieta. Quizás encontremos en una realidad como esta parte de la explicación del enorme consumo del fruto del algarrobo, sin olvidarnos tampoco que este era también complemento esencial de los grupos cultivadores.

\section{Conclusión}

¿Qué podemos sacar en limpio de la heterogeneidad de fenómenos y referencias acerca del trigo, la cebada y otros cultivos de España presentados anteriormente? Primero, y respetando el orden precedente, podemos afirmar que estos cultivos ingresaron al NOA en las primeras oleadas fundadoras, después de 1550, y que no hay elementos para suponer que las expediciones anteriores de Diego de Almagro o de Diego de Rojas hubieran participado de la dispersión de los mismos. Según nuestra búsqueda, sería Chile el centro de origen de las primeras semillas cultivadas con éxito a mediados de la década de 1550. Cabe la posibilidad de que las primeras semillas para el consumo llegaran a fines de 1553 por orden de Francisco de Aguirre, cuando se hizo cargo de Santiago del Estero, pero nuestra información referente a este caso es de segunda mano y, por lo tanto, no nos permite ser conclusivos. En cambio, las expediciones de los años 1555-1556 están mejor documentadas y podemos afirmar que Mejía de Miraval introdujo semillas de trigo, cebada, vid e incluso algodón, y que luego de esto se cultivaron con éxito en una muy pobre y desabastecida Santiago del Estero. Este último poblado debe de haber sido el centro de dispersión local, del cual han de haberse abastecido las 
posteriores fundaciones de la región, aunque Chile seguiría jugando un rol fundamental, como en el caso de las fundaciones de Pérez de Zurita.

En cuanto a la otra arista de este trabajo, podemos decir que, como está bien establecido y documentado, la mano de obra que realizaba las tareas agrícolas era, por supuesto, aborigen. Desde aquí retomamos aquella pregunta que hiciera de vector principal en este trabajo: ¿estos cultivos introducidos por los españoles penetraron en las costumbres culinarias y alimentarias de quienes los cultivaban, $o$ sea, los indios? A pesar de que hemos visto cómo los españoles dejaban poco espacio y margen de tiempo para las propias sementeras indígenas, productos como el maíz nunca se dejaron de lado ni aún en las plantaciones del encomendero. Más allá de las brutales imposiciones y desprecio por lo nativo que demostraban los colonizadores, pareciera que los aborígenes continuaron aferrándose, dentro de lo posible, al maíz - que consideraban como el mejor alimento-, los porotos, el ají y la algarroba en proporciones altísimas. El trigo, la cebada y los otros estaban destinados a la dieta mayoritariamente española y tuvieron muy baja repercusión dentro de la dieta indígena durante el primer siglo y medio de la conquista. Nuestra explicación de un fenómeno tal está íntimamente relacionada con un enfoque que se introduce en lo más profundo de los aspectos de simbolización y significación dentro del fenómeno cultural. Los grupos humanos captan, analizan y estructuran el universo que los rodea por medio de su sistema cognitivo, conocido como sistema psíquico. Este funciona con signos y símbolos que son puestos a disposición de los individuos por el grupo social en el que estos nacen y crecen, y que será portador de determinadas características culturales que los acompañarán a lo largo de toda su vida. Los alimentos son parte fundamental de ese universo simbólico y se hallan arraigados en lo más íntimo de las costumbres y tradiciones que conforman la identidad de los grupos socioétnicos. A pesar de todo esto, no podríamos negar que deben de haber sido muy numerosos los casos donde en la "mesa india" se encontrara alguna especie de pan o potaje de trigo o cebada o alguna fruta del viejo mundo, pero nuestro objetivo está centrado en lo que en ciencias humanas y sociales se entiende por "costumbre" o "hábito", es decir, aquellas acciones que transitan lo rutinario y forman parte de un corpus de elementos conocidos como patrones culturales. De hecho, y en referencia a los casos de apropiación y consumo de los cultivos foráneos, hemos notado que cuando en los documentos se hace referencia a una entrega de trigo a los indígenas, "aparentemente para su consumo", esta hace parte de la manutención durante un período determinado de trabajo, ya sea de mita o de servicio personal. Podemos constatar que el carácter de dicha estructura laboral era una imposición del o los españoles beneficiados, sin ningún tipo de derecho a réplica para los indios. A veces aparece también el caso de un pago por el levantamiento de una cosecha de trigo con parte de la misma cosecha, pero casi siempre sucede lo mismo que en el caso anterior. Por otra parte, diferente era la situación de los indios de servicio en la casa de sus amos, donde las propias conductas y concepciones indias eran 
terminantemente anuladas en pro de un comportamiento prácticamente españolizado. Sin embargo, hallamos un caso como para sospechar de la posible aculturación de los sirvientes, ya que en la casa del encomendero se priorizaba el consumo de maíz para estos.

Otro factor que se debe tener en cuenta a la hora de evaluar los cambios en las costumbres alimentarias es el grado de imposición y, sobre todo, los fenómenos culturales que involucra. No es lo mismo una alteración en la esfera política que podría implicar un cambio en las jerarquías de lealtad y obediencia -un nuevo líder- que la imposición de un nuevo sistema de subsistencia o un nuevo modo de producción. Estos últimos traerán mayores consecuencias en los patrones culturales del grupo. Veámoslo a través de los grupos involucrados en este trabajo. Los grupos andinos en su mayoría eran sedentarios y agricultores. Además estaban habituados al pago de un tributo en trabajo y productos antes de la llegada de los españoles, debido a la expansión incaica hacia el noroeste argentino. La situación posconquista para los sometidos mantuvo una organización económica estructuralmente similar, si por un momento nos abstraemos de su carácter radicalmente más violento, que en algunos casos resultaba fatal. Pero estos grupos agricultores mantuvieron la base de su sistema de subsistencia e incluso muchos de ellos lograron conservar tierras comunitarias y perduraron por un tiempo relativamente prolongado. En cambio, los grupos cazadores-recolectores sometidos, como los de la llanura tucumano-santiagueña y los chaqueños capturados en las distintas entradas, perdieron todo vínculo con su anterior modo de vida. Ello está demostrado por el solo hecho de ser obligados a asentarse definitivamente en un territorio perfectamente delimitado y pasar a depender de la producción de alimentos para subsistir, situación sumamente dificultosa, dado el enorme grado de cambio cultural que requiere. Seguramente, en esta situación hallaremos la razón de la supervivencia de algunas de las viejas costumbres, como la recolección de algarroba para subsidiar el déficit alimentario. Ya habíamos hablado acerca del caso de los lules y de cómo las políticas desestructurantes hicieron posible que, debido a una forzada adaptación a las nuevas circunstancias, se allanara el camino para que productos como el trigo y otros cultivos se volvieran parte de la dieta cotidiana.

Ahora bien, concentrándonos en aquellos grupos que continuaron manteniendo parte de sus costumbres y una capacidad de cohesión vinculada a la propiedad de tierras de comunidad -lo que seguramente posibilitó su reproducción por algunos siglos más- encontramos una situación compleja a la hora de intentar explicar su relación con los nuevos productos agrícolas. La mayor parte de los investigadores de la historia colonial coinciden en afirmar que los grupos andinos del Tucumán colonial permanecían reacios a aceptar en sus patrones culinarios los diversos cultivos europeos. Algunos incluso se animan a esbozar un modelo explicativo para dar cuenta de este fenómeno. Los sociólogos chilenos Bengoa y Valenzuela, 
en un estudio del cambio cultural mapuche luego de la llegada española, realizan una comparación de las diferencias en el proceso de aculturación entre estos grupos nómades y los grupos andinos agricultores ${ }^{54}$. En su modelo, establecen que los mapuches presentaron una enorme flexibilidad para incorporar elementos de la cultura española, como los caballos, el ganado vacuno y lanar, las armas, las esposas blancas y, lo más importante para nosotros, el trigo. Todo esto fue posible gracias a una "situación de absoluta independencia política y de intransable

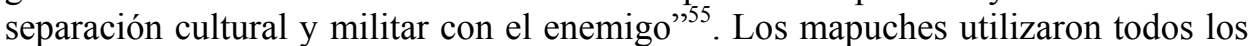
elementos ventajosos de los invasores para resignificarlos en su propio sistema cultural y sacar la mayor cantidad de ventajas de ellos. En cambio, en las sociedades andinas, según los mismos autores, la situación es diferente, debido a que fueron rápidamente sometidas -caso contrario de los mapuches, que fueron doblegados recién durante el siglo XIX- y de esta forma se cerraron culturalmente a la influencia externa, ya que, "al no poner distancia en el plano político y social necesitan reafirmar su identidad y esforzarse para sobrevivir culturalmente"

Este último modelo explicativo se torna sumamente atrayente, sobre todo si vemos con esta óptica los casos de la temprana adopción del trigo y la cebada por los grupos huarpes de Cuyo y los diaguitas-calchaquíes del noroeste, como habíamos visto en el apartado de introducción de estos productos en el NOA. Como estos grupos no estaban sometidos aún a los europeos, sus fronteras culturales permanecieron lo suficientemente flexibles como para aceptar los elementos foráneos sin que esto representara ningún peligro para su identidad. De esta manera, nuestra presentación concordaría perfectamente con lo señalado por los sociólogos chilenos y podría exponerse más o menos así: luego de la entrada y conquista de los españoles y la subsiguiente conformación de las primeras encomiendas, los indígenas impusieron barreras culturales herméticas frente a los elementos materiales que introducían los extranjeros del otro lado del Atlántico. Hemos podido corroborar que los cultivos europeos fueron de difícil introducción en la dieta aborigen de aquel momento. Sin embargo, existen ciertos elementos que no se articularían en una interpretación como la precedente. Si por un momento ampliamos la esfera de los elementos materiales que entraron con los españoles, nos topamos indefectiblemente con el ganado, y es sorprendente ver como este fue rápidamente adoptado por las culturas nativas ${ }^{57}$. En un trabajo específico sobre el tema, Estela Noli apunta que "las comunidades poseían ya en las primeras décadas del siglo XVII sus propios ganados y la carne ovina había sido incorporada a su dieta". ¿Debemos dejar de lado la idea de la resistencia andina hacia los productos

\footnotetext{
${ }^{54}$ José Bengoa y Eduardo Valenzuela, Economía mapuche. Pobreza y subsistencia en la sociedad mapuche contemporánea (Santiago de Chile: Editorial Pas, 1984).

${ }^{55}$ Ibídem, 30.

${ }^{56}$ Ibídem.

57 Véanse los trabajos de Noli, "La expansión de los ganados europeos"; Vázquez de Espinosa, Compendio y descripción; Baudot, La vida cotidiana.
} 
y costumbres españolas por la imposición de barreras culturales? No podríamos ser tan categóricos en uno ni en otro sentido. Tomaremos una posición mediadora donde la noción de resistencia cultural no será abandonada, porque consideramos que este concepto es una herramienta de análisis muy importante para abordar algunos fenómenos de las sociedades nativas en su relación con los europeos. La noción de resistencia cultural, íntimamente relacionada con la noción de identidad, puede ser puesta en la misma línea de análisis de los trabajos de supervivencia de estos grupos en relación con el mantenimiento de las tierras comunales y la manera como esto posibilita la puesta en marcha de estrategias de conjunto para obtener resultados más duraderos. Esta idea de resistencia está inevitablemente relacionada con la contingencia particular que significó la conquista, por lo tanto, no podemos perder de vista el factor de imposición violenta para analizar la introducción, el intercambio o la apropiación de elementos culturales.

De esta forma, entonces, debemos considerar que los indígenas de los siglos XVI y XVII, en lo que respecta al consumo cotidiano de productos agrícolas, como el trigo, la cebada y frutales, presentaron una barrera escasamente permeable y que esto puede ser interpretado como una especie de resistencia cultural ante los valores y costumbres del invasor que ponían en peligro los propios. Pero, ¿por qué esta resistencia parece ser selectiva con algunos productos y no así con otros? Como primera medida $-\mathrm{y}$, en cierta forma, esto es lo que venimos desarrollando-, los grupos sociales en contacto tienden a permeabilizar sus fronteras culturales ante ciertos aspectos que no ponen en peligro su identidad; de alguna manera, ese elemento foráneo resultaba beneficioso o interesante por algún motivo. Pero nuestro interés se concentra en aquellos caracteres o costumbres e incluso objetos que son partícipes de espacios conceptuales o simbólicos similares en relación con dos grupos culturales que entran en contacto. Denominaremos "nichos culturales" a aquellos espacios simbólicos conformados por un conjunto de categorías arbitrarias -construidas histórica y socialmente- con las cuales cada grupo social conformará conceptos para interactuar con el mundo que lo rodea y, dentro de este, con los objetos específicos que se vuelven significativos culturalmente. Los objetos con los que el grupo interactúa pueden abarcar múltiples categorías conceptuales o espacios de interacción (religioso, político, de subsistencia, etc.). De esta manera, la noción de concepto se aborda desde una perspectiva multidimensional, o sea, ubicando la interacción hombre-objeto en un espacio múltiple donde, dependiendo del contexto, incluirá alguna o algunas de las categorías con las cuales el grupo definirá aquel objeto. Ejemplo de esto es sin duda el caso del trigo para los españoles y el maíz para los indígenas americanos. Cada uno de estos cereales ha participado y ha cumplido un rol fundamental en la vida de los grupos humanos que estamos analizando. Conocemos el amplio valor otorgado por los grupos andinos al cultivo y consumo del maíz no solo en los aspectos económico y de subsistencia, sino también en su cosmogonía religiosa. El trigo también fue altamente valorado por los europeos y era fundamental en la mesa española, al 
punto de ser considerado la base de la dieta de aquel entonces. Ambos ocupaban nichos culturales similares por varios motivos. En primera medida, por lo recientemente expuestos, o sea, por el alto lugar que ocupaban en la vida cotidiana. Por otro lado, de ambos cultivos se obtienen granos, y así eran valorados tanto por españoles como por aborígenes, lo que los coloca en una misma categoría agrícola. También eran objeto de formas de procesamiento análogas, ya que se los molía para la producción de harina. Pero además podemos constatar que en la mesa cotidiana, por decirlo de alguna forma, con ambos productos se preparaba lo que se conoce como "pan". Si bien este término está siempre en relación directa con el trigo, conlleva también una noción más amplia, que define a todo producto básico en la dieta y la mesa cotidiana, la de algo hecho a base de la molienda de algún cereal y que generalmente es el complemento y acompaña cualquier otro plato. Así, de hecho, son los mismos españoles quienes hacen uso de este concepto cuando se refieren al "pan de las Indias" aludiendo a las gachas o tortas de maíz indígenas. Además de esta manera de preparación y cocción, existían otras como los potajes o "guisos" que podían realizarse con ambos alimentos, y de hecho así se hacía. Por otro lado, no menos importante es la relación de estos productos con el mundo religioso. No hay que olvidar la cercanía del trigo con la fe católica. La última cena o la transustanciación del cuerpo de cristo evidencian este fenómeno. Por otro lado, según lo ha demostrado J. V. Murra, en el mundo andino "se alimentaba con maíz a los dioses y a las momias de los reyes difuntos" ${ }^{98}$ y además era objeto de muchos otros rituales y ceremonias. Es nuestra intención remarcar aquí que los elementos culturales que ocupen un nicho específico y altamente valorado por un grupo opondrán una mayor resistencia a la introducción de elementos y caracteres de similar espacio conceptual que sea ajeno a esa cultura, y mayor aún será la resistencia ante fenómenos de imposición derivados de una conquista militar.

Bajo la misma óptica, podemos tratar de analizar el fenómeno de la adopción de los animales domésticos europeos y esbozar una explicación. Si bien los grupos andinos conocían muy bien las prácticas de manejo de ganado, hay que remarcar que la diferencia con las prácticas y usos europeos son notables. Primero, el número de especies domesticadas en los andes es muchísimo menor que el del Viejo Mundo. Apenas dos son las especies reconocidas para el NOA, el cuy o curí (Cavia porcellus) y la llama (Lama glama) ya que de la alpaca no hay evidencia en esta región. En cuanto a los usos de estos animales, se considera que las llamas eran de suma importancia por las funciones que cumplían en el transporte y la producción textil. En cuanto a la alimentación, se reconoce que, sobre todo para la época de ocupación incaica, jugaba un papel secundario en la dieta local restringiéndose sólo a los momentos festivos y ceremoniales. Además, la posesión del ganado era netamente de carácter estatal, teniendo los pastores solamente una

${ }^{58}$ J. V. Murra, La organización económica del Estado Inca (México, Siglo XXI, 1978). 
función como encargados del cuidado de los animales, sin opciones de utilizarlos libremente. En el momento poshispano, la situación cambia en el sentido de que ahora los particulares podían acceder a la posesión y disposición de animales domésticos, y es recién en este momento que comienza a ser importante en la dieta de los aborígenes la carne de dichos animales y, por ende, en sus costumbres culinarias. Por lo tanto, podemos considerar que las relaciones con los animales domésticos son muy distintas antes y después de la conquista española y que los nichos culturales ocupados en cada caso eran muy diferentes, lo cual no presenta ninguna contradicción con las concepciones que se tenía de uno u otro tipo de ganado.

Existen otros factores que también ayudarían a comprender y explicar la escasa participación de los cultivos foráneos en la dieta nativa, pero en este caso son factores que se vuelcan más hacia conveniencias españolas que a la resistencia aborigen. Muchas veces las mismas estrategias comerciales del grupo dominante chocaban con la manutención de su propia mano de obra, los indios. En efecto, ante la falta de riquezas minerales en el Tucumán, los españoles tuvieron que adoptar otras estrategias para sobrevivir, por un lado, e incorporarse en el mercado colonial, por el otro. Por ello, vemos que los excedentes productivos eran logrados con productos textiles, en mayor medida, los frutos de la recolección, como la miel y la cera, y lo más importante para nosotros, los productos agrícolas. Como habíamos visto, el Tucumán fue por un período de su historia un centro abastecedor de cereales, sobre todo de trigo, a otras regiones del virreinato e incluso a lugares distantes, como África y Brasil. Grosso modo, al ser estos productos altamente comercializables, es probable que se diera una situación donde los mismos encomenderos intentaran extraer el máximo posible de la producción agrícola, para así comercializarla y obtener ganancia en metálico o introducir productos faltantes. Entonces no sería tan descabellado pensar que muchas veces los mismos españoles extraerían la totalidad de los cultivos de las tierras comunales sin dejar posibilidad para el consumo aborigen, alentando en muchos casos estrategias alternativas para la subsistencia de su propia mano de obra. Esto podríamos relacionarlo directamente con la reglamentación de ordenanzas para la recolección de la algarroba, por ejemplo, donde intentan controlar e introducir en la economía colonial las alternativas de subsistencia indígenas.

Por último, quisiéramos añadir una fuente de información diferente de la que hemos tomado hasta aquí. Los trabajos arqueológicos pocas veces ayudan a dilucidar hechos históricos específicos, pero son excelentes indicadores de patrones y comportamientos culturalmente significativos, sobre todo en relación con la manipulación de objetos en contextos sociales diversos. Es interesante traer a colación los resultados de una excavación arqueológica en el pueblo de Londres de Quimivil, en la actual provincia de Catamarca, región que formara parte de la antigua jurisdicción del Tucumán colonial. Este sitio, según recientes 
interpretaciones ${ }^{59}$, posee dos ocupaciones temporalmente bien diferenciadas a manera de eventos: "evento I o Inka" y "evento II o Hispano-Indígena". Este último es el que mas nos interesa aquí ya que ha permitido establecer una ocupación aborigen (de posible filiación diaguita) comprendida entre los años 1600-1640. Lo extraordinario de estos hallazgos, entre los que se cuentan numerosas semillas de trigo, cebada y frutales de España, es que han permitido develar cierto grado y contexto de utilización de objetos españoles por parte de los aborígenes. Lo extraordinario es que aparentemente los objetos hispánicos no se hallaron en contextos domésticos o utilitarios, sino que hacen su aparición en un contexto específicamente ritual, como es el ushnu o plataforma ceremonial de origen incaico. Fuera de esta estructura, se hallaron solamente objetos y productos de filiación netamente aborigen (cerámica caspinchango estilo hispano-indígena ${ }^{60}$, algarrobo, maíz, etc.). Si nos guiamos por el contexto de hallazgo de los cultivos en este sitio, parece ser que los mismos estaban siendo manipulados, pero no consumidos. Esto surge a partir del hecho de que tanto el trigo como la cebada y los frutales no aparecieron en recintos de habitación y solo estaban presentes en la estructura ceremonial como participando posiblemente en uno o más rituales ${ }^{61}$. Esta última información apoyaría de alguna forma toda la interpretación previamente presentada, aunque no es nuestra intención presentarla como un cuerpo sólido de evidencia irrefutable, ya que numerosas dudas pueden surgir y no hallar una respuesta rápida. Podríamos preguntarnos, por ejemplo, si esto se extiende a la totalidad del territorio del Tucumán colonial, o, por otro lado, por qué estos objetos hacían parte de los rituales, pues las respuestas cambiarían mucho el potencial de las interpretaciones.

Hasta aquí hemos analizado la compleja problemática de la introducción de los cultivos europeos en el noroeste argentino y su relación con las poblaciones nativas desde distintos enfoques, que han incluido tanto concepciones aborígenes como españolas. El fenómeno tiene múltiples aristas y aquí se han alcanzado solo algunas, por lo que consideramos que este trabajo no debería ser abordado de manera conclusiva, sino, más bien, como una fuente de ideas para encarar trabajos futuros que puedan engrosar el conocimiento de la historia de los grupos humanos de la región. La arqueología, sin duda, podrá aportar mucho al respecto, y la complementariedad con la historia y la etnohistoria multiplicaría exponencialmente los resultados que cada una podría aportar por separado.

\footnotetext{
${ }^{59}$ R. Raffino y otros, "El ushnu de El Shincal de Quimivil", Tawantinsuyu (Canberra, Australia), 3 (1999): 22-39.

${ }^{60}$ En arqueología, el estilo cerámico conocido como hispano-indígena hace referencia a la fabricación de elementos aborígenes en un determinado período temporal posconquista y no tiene vinculación con objetos de origen español.

${ }^{61}$ Raffino, "El ushnu de El Shincal”.
} 


\section{Bibliografía}

\section{Fuentes primarias}

Archivo General de Indias (Sevilla)

\section{Fuentes secundarias}

Arana, M. M. "El tiempo de la algarroba”. En En los tres reinos: prácticas de recolección en el cono sud de América, eds. C. A. Aschero, M. A. Korstanje y P. M. Vuoto. Tucumán: UNT, Magna Publicaciones, 1999.

Argerich, Raúl. Historia de Londres. Catamarca: Municipalidad de Londres, 2000.

Báez, J. R. "La primera colonia agrohispana en el Tucumán (siglo XVI)”. Revista Argentina de Agronomía (Buenos Aires), 14, núm. 2 (1947): 85-93.

- "La primera colonia agrohispana en Cuyo (siglo XVI)". Revista Argentina de Agronomía (Buenos Aires), 15, núm. 1 (1948): 19-32.

Baudot, G. La vida cotidiana en la América española en tiempos de Felipe II. México: Fondo de Cultura Económica, 1995.

Bengoa, José y Eduardo Valenzuela. Economía mapuche. Pobreza y subsistencia en la sociedad mapuche contemporánea. Santiago de Chile: Editorial Pas, 1984.

Berberian, E. Crónicas del Tucumán. Siglo XVI. Comechingonia, Argentina: UNC, 1987.

Boixados, Roxana. "Los pueblos de indios de La Rioja colonial. Tierra, trabajo y tributo en el siglo XVII”. En Los pueblos de indios del Tucumán colonial, comps. J. Farberman y R. Gil Montero. Jujuy, Argentina: Ediunju; UNQ, 2002.

Capparelli, A. y R. Raffino. Arqueobotánica de El Shincal I: Tallos finos, frutos y semillas. Vol. 3. Tawantinsuyu (Sydney, Australia: Brolga Press, 1997.

Castro Olañeta, Isabel. "Recuperar las continuidades y transformaciones: las 'juntas' y borracheras de los indios de Quilino y su participación en la justicia colonial". En Los pueblos de indios del Tucumán colonial, comps. J. Farberman y R. Gil Montero. Jujuy, Argentina: Ediunju; UNQ, 2002. 
Doucet, G. "Los réditos de Quilpo. Funcionamiento de una encomienda cordobesa a fines del siglo XVI (1595-1598)". Jahrbuch für Geschichte von Staat, Wirtschaft und Gesselschaft Lateinamerikas (Colonia, Alemania), s. n. (1986): 63-119.

Farberman, J. "Feudatarios y tributarios a fines del siglo XVII. Tierra, tributo y servicio personal en la visita de Luján de Vargas a Santiago del Estero (1693)". En Los pueblos de indios del Tucumán colonial, comps. J. Farberman y R. Gil Montero. Jujuy, Argentina: Ediunju; UNQ ,2002.

Larrouy, A. Documentos relativos a Nuestra Señora del Valle y a Catamarca, t. 1. Buenos Aires: Compañía Sudamericana de Billetes de Banco, 1915.

Levillier, R. "Gobernación del Tucumán. Probanzas de méritos y servicios de los conquistadores". En Documentos de Archivo de Indias. Colección de publicaciones históricas de la Biblioteca del Congreso Argentino. Madrid: Sucesores de Rivadeneyra, 1919-1920.

Lizondo Borda, Manuel. Historia de la Gobernación del Tucumán (Siglo XVI). Buenos Aires: Publicación de la Universidad de Tucumán, 1928.

López de Albornoz, C. y A. M. Bascari, "Pueblos de indios de Colalao y Tolombón: Identidad colectiva y articulación étnica y social (siglos XVIIXIX)”. Humanitas (Tucumán, Argentina), 27 (1998): 63-119.

López de Gomara, Francisco. Historia general de las Indias, ed. German Vázquez. 1552; reimpresión, Madrid: Historia 16, 1987.

Lorandi, A. M. "El servicio personal como agente de desestructuración en el Tucumán colonial”. Revista Andina (Cusco, Perú), año 6, núm. 1 (1988): 135-173.

Noli, Estela. "La recolección en la economía de subsistencia de las poblaciones indígenas: una aproximación a través de las fuentes coloniales (piedemonte y llanura tucumano-santiagueña). Gobernación del Tucumán”. En En los tres reinos: prácticas de recolección en el cono sud de América, eds. C. A. Aschero, M. A. Korstanje y P. M. Vuoto. Tucumán, Argentina: UNT, Magna Publicaciones, 1999.

. "La expansión de los ganados europeos: cambios en la economía y cultura material de las poblaciones indígenas de San Miguel de Tucumán 
(1600-1620)". Actas del XII Congreso Nacional de Arqueología Argentina, La Plata: UNLP, 1999.

Murra, J. V. La organización económica del Estado Inca. México, Siglo XXI, 1978.

Quiroga, A. Calchaquí, comentarios de actualización R. Raffino. Buenos Aires: TEA, 1992.

Raffino, R. y otros. "El ushnu de El Shincal de Quimivil". Tawantinsuyu (Camberra, Australia), 3 (1999): 22-39.

Sica, Gabriela. "Vivir en una chacra de españoles: encomienda, tierra y tributo en el pueblo de San Francisco de Paipaya, Jujuy, siglo XVII". En Los pueblos de indios del Tucumán colonial, comps. J. Farberman y R. Gil Montero. Jujuy, Argentina: Ediunju; UNQ, 2002.

Sotelo de Narváez, P. "Relación de las provincias del Tucumán que dio Pedro Sotelo Narváez, vecino de aquellas provincias, al muy ilustre señor Licenciado Cepeda, Presidente desta Real Audiencia de La Plata", 1583. En Crónicas del Tucumán. Siglo XVI. E. Berberian, 235-243. Comechingonia, Argentina, 1987.

Torres, F. "Agricultura y conflictos en la Córdoba colonial". Todo es Historia (Buenos Aires), año 17, núm. 201 (1984): 38-58.

Vázquez de Espinosa, A. Compendio y descripción de las Indias Occidentales. Crónicas de América 68b. 1628; reimpresión, Madrid: Editorial Historia 16, 1992.

Warman, Arturo. La historia de un bastardo, maíz y capitalismo. México: Fondo de Cultura Económica, 1974.

Fecha de recepción: 4 de mayo de 2005.

Fecha de aceptación: 23 de agosto de 2005. 